\title{
A Guide to Foreign Exchange Markets
}

\author{
K. Alec Chrystal
}

$\mathbf{T}$ increasingly interdependent. U.S. exports now amount to almost 10 percent of Gross National Product. For both Britain and Canada, the figure currently exceeds 25 percent. Imports are about the same size. Trade of this magnitude would not be possible without the ability to buy and sell currencies. Currencies must be bought and sold because the acceptable means of payment in other countries is not the U.S. dollar. As a result, importers, exporters, travel agents, tourists and many others with overseas business must change dollars into foreign currency and/or the reverse.

The trading of currencies takes place in foreign exchange markets whose majof function is to facilitate international trade and investment. Foreign exchange markets, however, are shrouded in mystery. One reason for this is that a considerable amount of foreign exchange market activity does not appear to be related directly to the needs of international trade and investment.

The purpose of this paper is to explain how these markets work. The basics of foreign exchange will first

K. Alec Chrystal, professor of economics-elect, University of Sheffield, England, is a visiting scholar at the Federal Reserve Bank of St. Louis. Lestie Bailis Koppel provided research assistance. The author wishes to thank Joseph Hempen, Centerre Bank, St. Louis, for his advice on this paper.

${ }^{1}$ For further discussion of foreign exchange markets in the United States, see Kubarych (1983). See also Dufey and Giddy (1978) and McKinnon (1979). be described. This will be followed by a discussion of some of the more important activities of market participants. Finally, there will be an introduction to the analysis of a new feature of exchange markets - currency options. The concern of this paper is with the structure and mechanics of foreign exchange markets, not with the detemminants of exchange rates themselves.

\section{THE BASTCS OF POREIGN EXCHANGE MARKETS}

There is an almost bewildering variety of foreign exchange markets. Spot markets and forward markets abound in a number of currencies. In addition, there are divense prices quoted for these currencies. This section attempts to bring order to this seeming disarray.

\section{Spot, Forward, Bid, Ask}

Virtually every major newspaper, such as the Wall Street Journal or the London Financial Times, prints a daily list of exchange rates. These are expressed either as the number of units of a particular currency that exchange for one U.S. dollar or as the number of U.S. dollars that exchange for one unit of a particular currency. Sometimes both are listed side by side (see table 1).

For major currencies, up to four different prices typically will be quoted. One is the "spot" price. The others may be "30 days forward," "90 days forward," 


\section{Table 1}

\section{Foreign Exchange Rate Quotations}

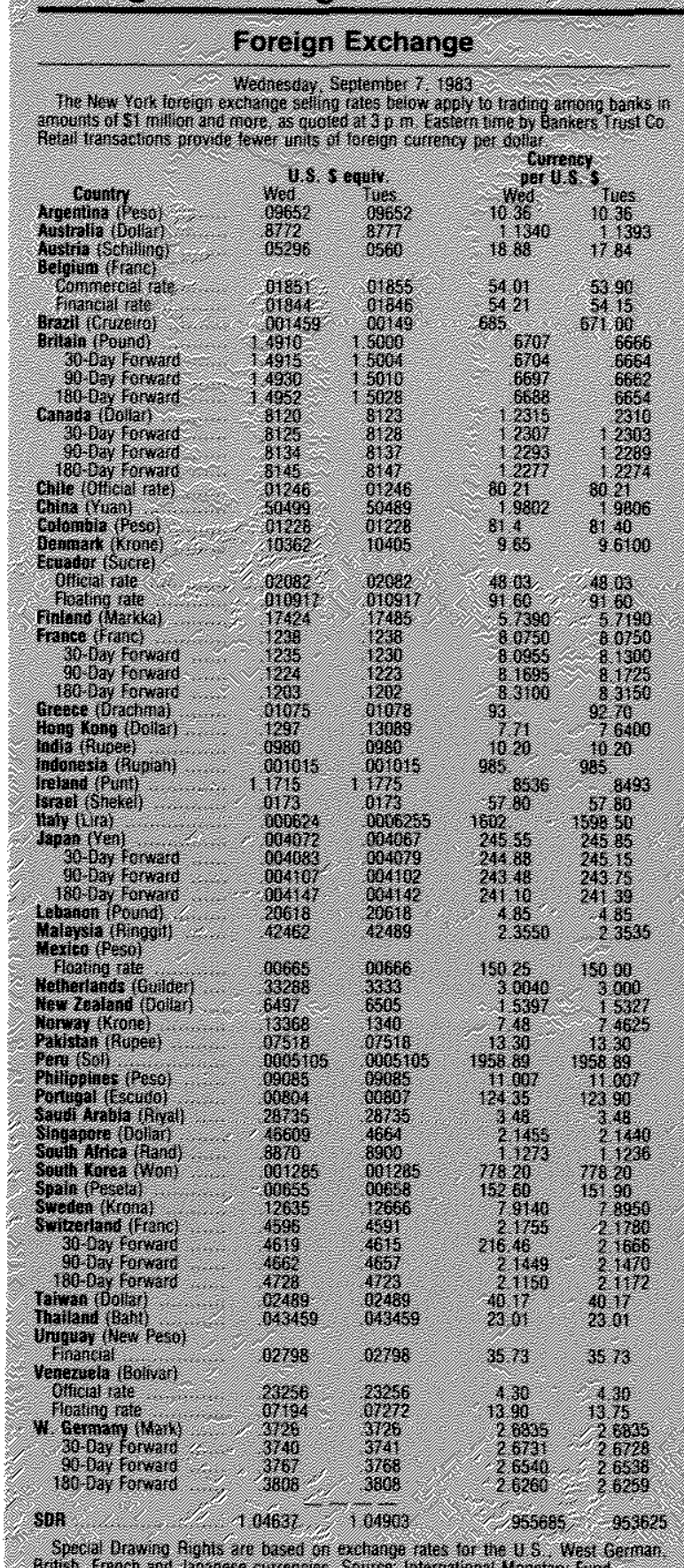

6.7.

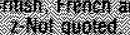

\section{The Dollar Spot and Forward}

\begin{tabular}{|c|c|c|c|c|c|c|}
\hline sotes & 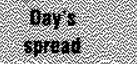 & $96 \times$ & None riogn & (2) & proes & it \\
\hline & 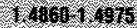 & $1,410 x+1960$ & 1) 240 th is & 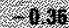 & $0,17+2,2118$ & \\
\hline 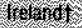 & $1 \times 167,178$ & (1) $11011,12 \%$ & $0,61,101 \%$ & 9.9 & $060 \% 170$ & 1 \\
\hline (2) & $1,235 \% 128$ & $10+210,2,15$ & $9140,10164)$ & $0.1 \%$ & $0,24,0240$ & ( ) \\
\hline netwition & 1901014060 & $2 / 100,0 \times 070$ & $1,1, x, 00110$ & 42 & 800.6100 & 的 \\
\hline int & $5 \% 1006$ & $10101 \%, 10$ & $7+4,9 n$ & 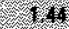 & $14+110$ & 10 \\
\hline $860 \% 10 \mathrm{x}$ & 101640096060 & $66400 \times 195$ & $272 \mathrm{ntm} / \mathrm{LS}$ & 275 & 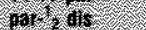 & 6 \\
\hline r 6 & 26050460 & $2 \gamma 606 \% 270$ & $1,07,1, ; / 12$ & 46 & 80028907 & 61 \\
\hline 16126 & $174<6012600$ & $14,40,7,7$ & 11524006 & -1961 & (6) 117 51016 & 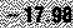 \\
\hline Sbow & 152,16472 & $-5 \%, 01 \% 7,6$ & $170,240,4$ & -15 & 1045,7545 & -28 \\
\hline 14 & $-161 \times 161$ & 10641615 & (10.16)1, & $-1,6$ & 20,1610 & -4 \\
\hline 16014 & $7 \% 180 \% 19$ & $7,1,60,4700$ & $1 / 902700000$ & 2,3 & 60062068 & -1 \\
\hline 8 & 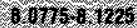 & $6010 \%, 506$ & $202,10,01$ & $2=31$ & 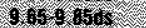 & \\
\hline teret & $7,0100,096$ & 170120,4810 & 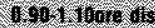 & (1) 1 , 1 & $2262.41 \%$ & - 1 \\
\hline $8 \%$ & $246.14,6106$ & $240,0,25,45$ & $0,61,6,04,101 \%$ & 8 & 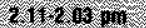 & 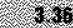 \\
\hline 46 & $10 \% 101096$ & $1060 \times 10,6$ & 2,50167000010 & 45 & 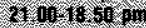 & 11 \\
\hline & 2 $17 \pi$ o $10 \%$ & $2,14010,2,15$ & 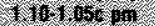 & 501 & 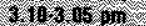 & 68 \\
\hline
\end{tabular}

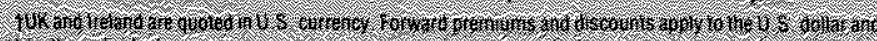

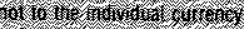

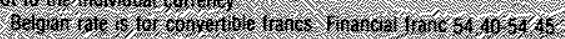

London Einancial Times, September 8, 1983

Wall Sireet Joumal. September 6,1983 
and " 180 days forward." These may be expressed either in "European Terms" (such as number of $\$$ per $E$ ) or in "American Terms" (such as number of $E$ per \$). (See the glossary for further explanation.)

The spot price is what you must pay to buy currencies for immediate delivery two working days in the interbank market; over the counter, if you buy bank notes or travelers checks). The forward prices for each currency are what you will have to pay if you sign a contract today to buy that currency on a specific future date 130 days from now, etc.l. In this market, you pay for the currency when the contract matures.

Why would anyone buy and sell foreign currency forward? There are some major advantages from having such opportunities available. For example, an exporter who has receipts of foreign currency due at some future date can sell those funds forward now, thereby avoiding all risks associated with subsequent adverse exchange rate changes. Similarly, an importer who will have to pay for a shipment of goods in foreign currency in, say, three months can buy the foreign exchange forward and, again, avoid having to bear the exchange rate risk.

The exchange rates quoted in the financial press (for example, those in table 1) are not the ones individuals would get at a local bank. Unless otherwise specified, the published prices refer to those quoted by banks to other banks for currency deals in excess of $\$ 1$ million. Even these prices will vary somewhat depending upon whether the bank buys or sells. The difference between the buying and selling price is sometimes known as the "bid-ask spread." The spread partly reflects the banks' costs and profit margins in transactions; however, major banks make their profits more from capital gains than from the spread. ${ }^{2}$

The market for bank notes and travelers checks is quite separate from the interbank foreign exchange market. For smaller currency exchanges, such as an individual going on vacation abroad might make, the spread is greater than in the interbank market. This presumably reflects the larger average costs - including the exchange rate risks that banks face by holding bank notes in denominations too small to be sold in the interbank market - associated with these smaller exchanges. As a result, individuals generally pay a higher price for foreign exchange than those quoted in the newspapers.

\footnotetext{
${ }^{2}$ Notice the Walf Street Journal quotes only a bank selling price at a particular time. The Financial Times quotes the bid-ask spread and the range over the day.
}

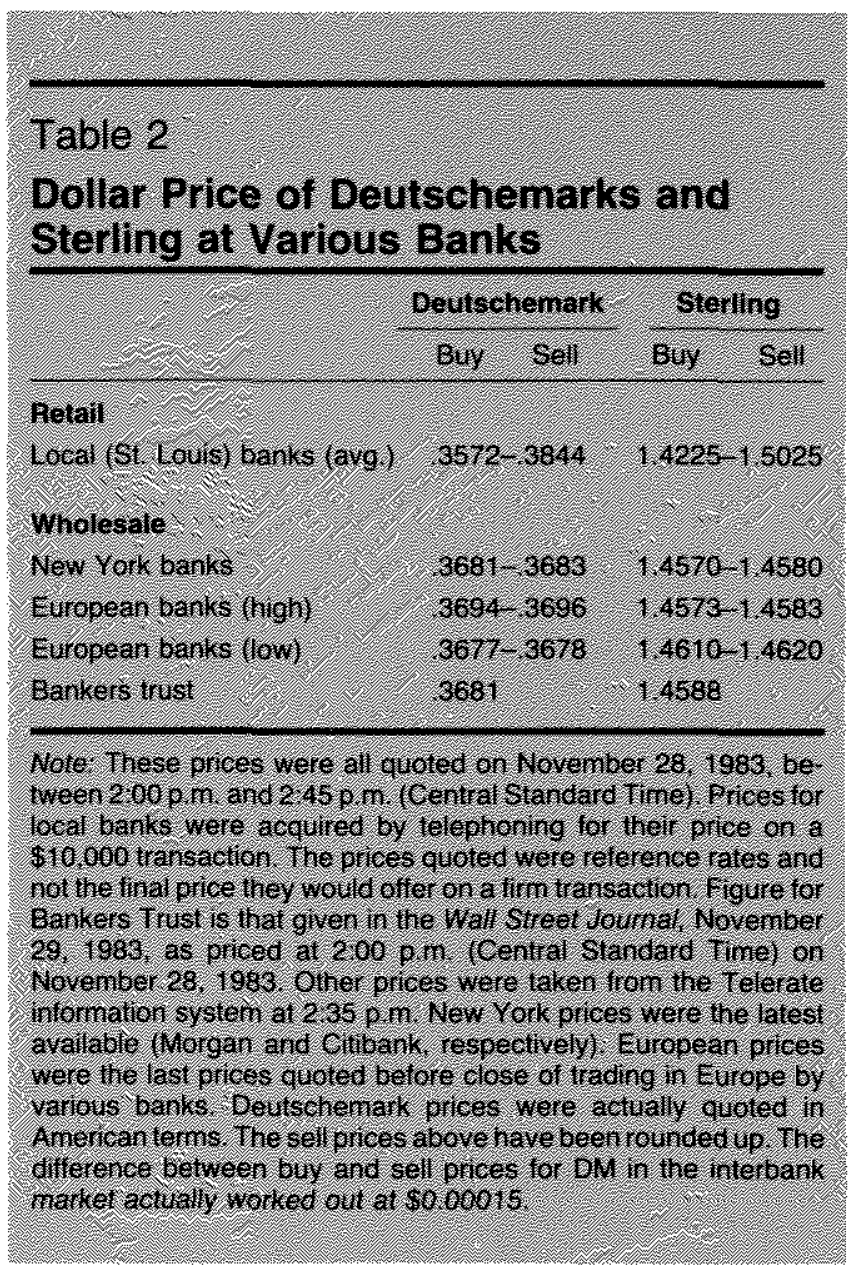

An example of the range of spot exchange rates available is presented in table 2, which shows prices for deutschemarks and sterling quoted within a one-hour period on November 28, 1983. There are two important points to notice. First, all except those in the first line are prices quoted in the interbank, or wholesale, market for transactions in excess of $\$ 1$ million. The sterling prices have a bid-ask spread of only 0.1 cent (which is only about 0.07 percent of the price, or $\$ 7$ on $\$ 10,000$ ). On DM, the spread per dollars worth works out to be about half that on sterling $(\$ 4 \text { on } \$ 10,000)^{3}$

Second, the prices quoted by local banks for small, or retail, transactions, which serve only as a guide and do not necessarily represent prices on actual deals, involve a much larger bid-ask spread. These retail spreads vary from bank to bank, but are related to (and larger than the interbank rates. In some cases, they

\footnotetext{
${ }^{3}$ In practice, the spread will vary during the day, depending upon matket conditions. For example, the sterling spread may be as little as 0.01 cents at times and on average is about 0.05 cents. Spreads generally will be larger on less widely traded currencies.
} 
may be of the order of 4 cents or less on sterling, though the prices quoted in St. Louis involved average spreads of 8 cents on sterling. The latter represents a spread of about $5 \frac{1}{2}$ percent (about $\$ 550$ per $\$ 10,000$ transaction). The equivalent spread for DM was 7 percent $1 \$ 700$ per $\$ 10,000$ transaction).

The spread on forward transactions will usually be wider than on spot, especially for longer maturities. For interbank trade, the closing spread on one and three months forward sterling on September 8, 1983, was .15 cents, while the spot spread was 10 cents. This is shown in the top line of the Financial Times report in table 1. Of course, like the spot spread, the forward spread varies with time of day and market conditions. At times it may be as low as .02 cents. No information is available for the size of spread on the forward prices typically offered on small transactions, since the retail market on forward transactions is very small.

\section{HOW DOES “THE” FOREIGN EXCHANGE MARKET OPERATE?}

It is generally not possible to go to a specific building and "see" the market where prices of foreign exchange are determined. With few exceptions, the vast bulk of foreign exchange business is done over the telephone between specialist divisions of major banks. Foreign exchange dealers in each bank usually operate from one room; each dealer has several telephones and is surrounded by video screens and news tapes. Typically, each dealer specializes in one or a small number of markets Isuch as sterling/dollar or deutschemark/dollar. Trades are conducted with other dealers who represent banks around the world. These dealers typically deal regularly with one another and are thus able to make firm commitments by word of mouth.

Only the head or regional offices of the larger banks actively deal in foreign exchange. The largest of these banks are known as "market makers" since they stand ready to buy or sell any of the major currencies on a more or less continuous basis. Unusually large transactions, however, will only be accommodated by market makers on more favorable terms. In such cases, foreign exchange brokers may be used as middlemen to find a taker or takers for the deal. Brokers (of which there are four majot firms and a handful of smaller ones) do not trade on their own account, but specialize in setting up large foreign exchange transactions in return for a commission (typically 0.03 cents or less on the sterling spread). In April 1983, 56 percent of spot transactions by value involving banks in the United States were channeled through brokers, ${ }^{4}$ If all interbank transactions are included, the figure rises to 59 percent.

Most small banks and local offices of major banks do not deal directly in the interbank foreign exchange market. Rather they typically will have a credit line with a large bank or their head office. Transactions will thus involve an extra step (see figure 1 ). The customer deals with a local bank, which in turn deals with a major bank of head office. The interbank foreign exchange market exists between the major banks either directly or indirectly via a broker.

\section{FUTURES AND OPTION MARKETS FOR FOREIGN EXCHANGE}

Until very recently, the interbank market was the only channel through which foreign exchange transactions took place. The past decade has produced major innovations in foreign exchange trading, On May 16 , 1972 , the International Money Market (IMM) opened under the auspices of the Chicago Mercantile Exchange. One novel feature of the IMM is that it provides a trading floor on which deals are struck by brokers face to face, rather than over telephone lines. The most significant difference between the IMM and the interbank market, however, is that trading on the IMM is in futures contracts for foreign exchange, the typical business being contracts for delivery on the third Wednesday of March, June, September or December. Activity at the IMM has expanded greatly since its opening. For example, during $1972,144,336$ contracts were traded; the figure for 1981 was $6,121,932$.

There is an important distinction between "forward" transactions and "futures" contracts. The former are individual agreements between two parties, say, a bank and customer. The latter is a contract traded on an organized market of a standard size and settlement date, which is resalable at the market price up to the close of trading in the contract. These organized markets are discussed more fully below.

While the major banks conduct foreign exchange deals in large denominations, the IMM trading is done in contracts of standard size which are fairly small. Examples of the standard contracts at present are $£ 25,000$; DM125,000; Canadian $\$ 100,000$. These are actually smaller today than in the early days of the IMM.

Further, unlike prices on the interbank market, price movements in any single day are subject to specific

${ }^{4}$ See Federal Reserve Bank of New York (1983). 


\section{Figure 1}

\section{Structure of Foreign Exchange Markets}

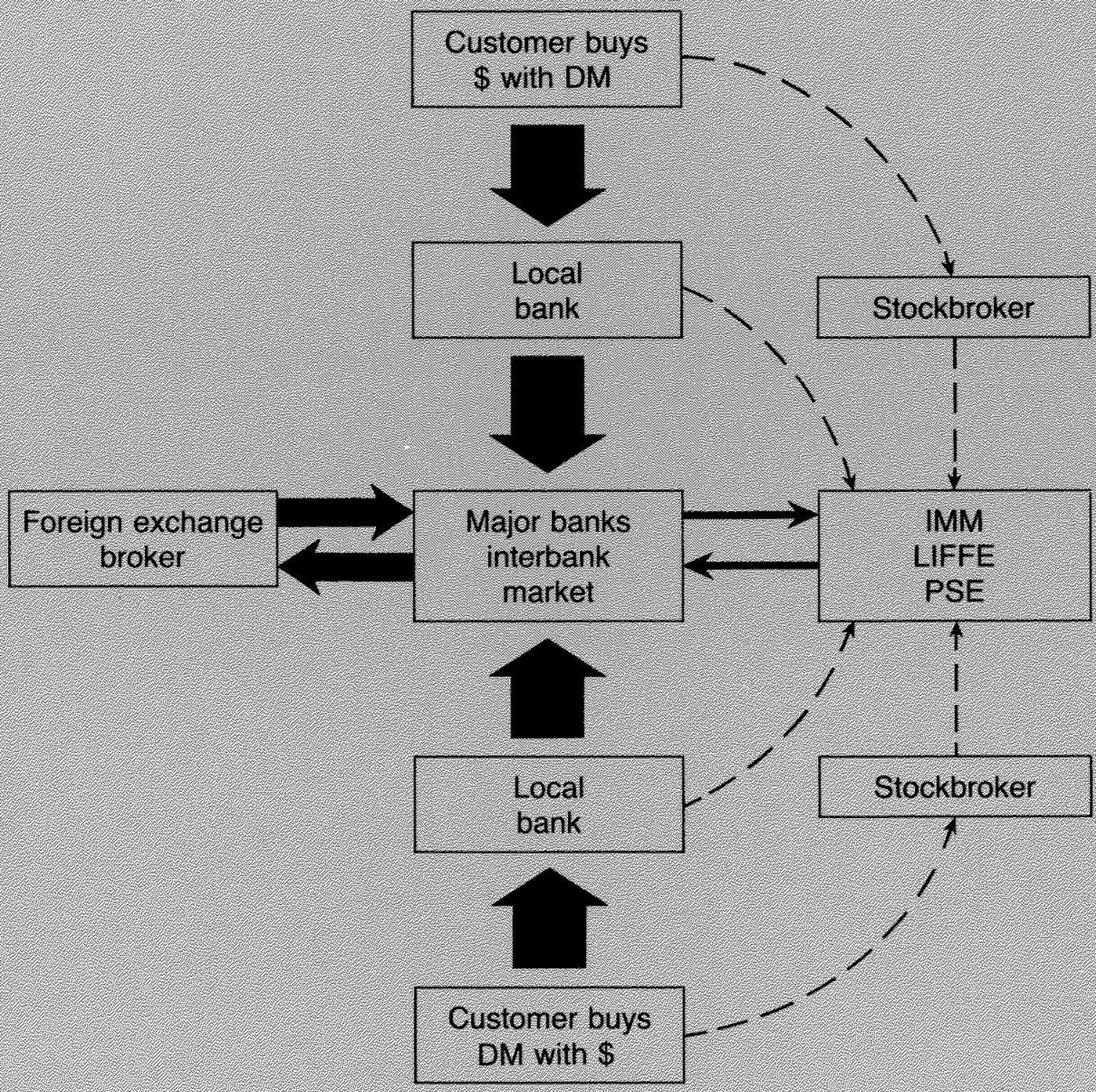

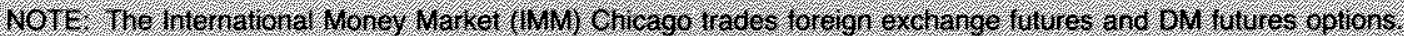

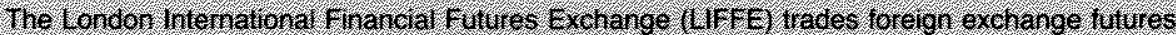
The Philadelphia stock Exchange (PSE) hades toregro currency oplojs. 
limits at the IMM. For example, for sterling futures, prices are not allowed to vary more than $\$ .0500$ away from the previous day's settlement price; this limit is expanded if it is reached in the same direction for two successive days. The limit does not apply on the last day a contract is traded.

Unitke the interbank market, parties to a foreign exchange contract at the IMM typically do not know each other Default risk, however, is minor because contracts are guaranteed by the exchange itself. To minimize the cost of this guarantee, the exchange insists upon "margin requirements" to cover fluctuations in the value of a contract. "This means that an individual on firm buying a futures contract would, in effect, place a deposit equal to about 4 percent of the value of the contract. ${ }^{5}$

Perhaps the major limitation of the IMM from the point of view of importers or exporters is that contracts cover only eight currencies - those of Britain, Canada, West Germany, Switzerland, Japan, Mexico, France and the Netherlands - and they are specified in standard sizes for particular dates. Only by chance will these conform exactly to the needs of importers and exporters. Large firms and financial institutions will find the market useful, however, if they have a fairly continuous stream of payments and receipts in the traded foreign cutrencies. Although contracts have a specified standard date, they offer a fairly flexible method of avoiding exchange rate risk because they are marketable continuously.

A major economic advantage of the IMM for nonbank customers is its low transaction cost. Though the brokerage cost of a contract will vary, a "round trip" that is, one buy and one sell) costs as little as $\$ 15$. This is only .04 percent of the value of a sterling contract and less for some of the larger contracts. Of course, such costs are high compared with the interbank market, where the brokerage cost on DM 1 million would be about $\$ 6.25$ the equivalent-valued eight futures contracts would cost $\$ 60$ in brokerage, taking $\$ 7.50$ per single deall. They are low, however, compared with those in the retail market, where the spread may involve a cost of up to 2.5 percent or 3 percent per transaction.

A market similar to the IMM, the London International Financial Futures Exchange (LFFE), opened in September 1982. On LIFFE, futures are traded in ster-

${ }^{5} \mathrm{~A}$ bank may also insist upon some minimum deposit to cover a forward contract, though there is no firm rule. ling, deutschemarks, Swiss francs and yen in identical bundles to those sold on the IMM. In its first year, the foreign exchange business of LIFFE did not take off in a big way. The major provider of exchange rate risk coverage for business continues to be the bank network. Less than 5 percent of such cover is provided by markets such as IMM and LIFFE at present.

An entirely new feature of foreign exchange markets that has arisen in the 1980 s is the existence of option markets. The Philadelphia Exchange was the first to introduce foreign exchange options. These are in five currencies ldeutschemark, sterling, swiss franc, yen and Canadian dollax. Trades are conducted in standard bundles half the size of the IMM futures contracts. The IMM introduced an options market in German marks on January 24, 1984; this market trades options on futures contracts whereas the Philadelphia options are for spot currencies.

Futures and options prices for foreign exchange are published daily in the financial press. Table 3 shows prices for February 14, 1984, as displayed in the Wall Street Journal on the following day. Futures prices on the IMM are presented for five currencies (left-hand column!. There are five contracts quoted for each cur rency: March, June, September, December and March 1985. For each contract, opening and last settlement isettlel prices, the range over the day, the change from the previous day, the range over the life of the contract and the number of contracts outstanding with the exchange (open interest) are listed.

Consider the March and June DM futures. March futures opened at $\$ .3653$ per mark and closed at $\$ .3706$ per mark; June opened at $\$ .3698$ per mark and closed at $\$ .3746$ per mark. Turn now to the Chicago Mercantile Exchange (IMM) futures options (center column). These are options on the futures contracts just discussed (see inset for explanation of options). Thus, the line labeled "Futures" lists the settle prices of the March and June futures as above.

Let us look at the call options. These are rights to buy DM futures at specified prices - the strike price. For example, take the call option at strike price 35 . This means that one can purchase an option to buy DM 125,000 March futures up to the March settlement date for $\$ .3500$ per mark. This option will cost 2.05 cents per mark, or $\$ 2,562.50$, plus brokerage fees. The June option to buy June futures DM at $\$ .3500$ per mark will cost 2.46 cents per mark, or $\$ 3,075.00$, plus brokerage fees.

\footnotetext{
${ }^{6}$ For a discussion of options in commodities, see Belongia (1983).
} 


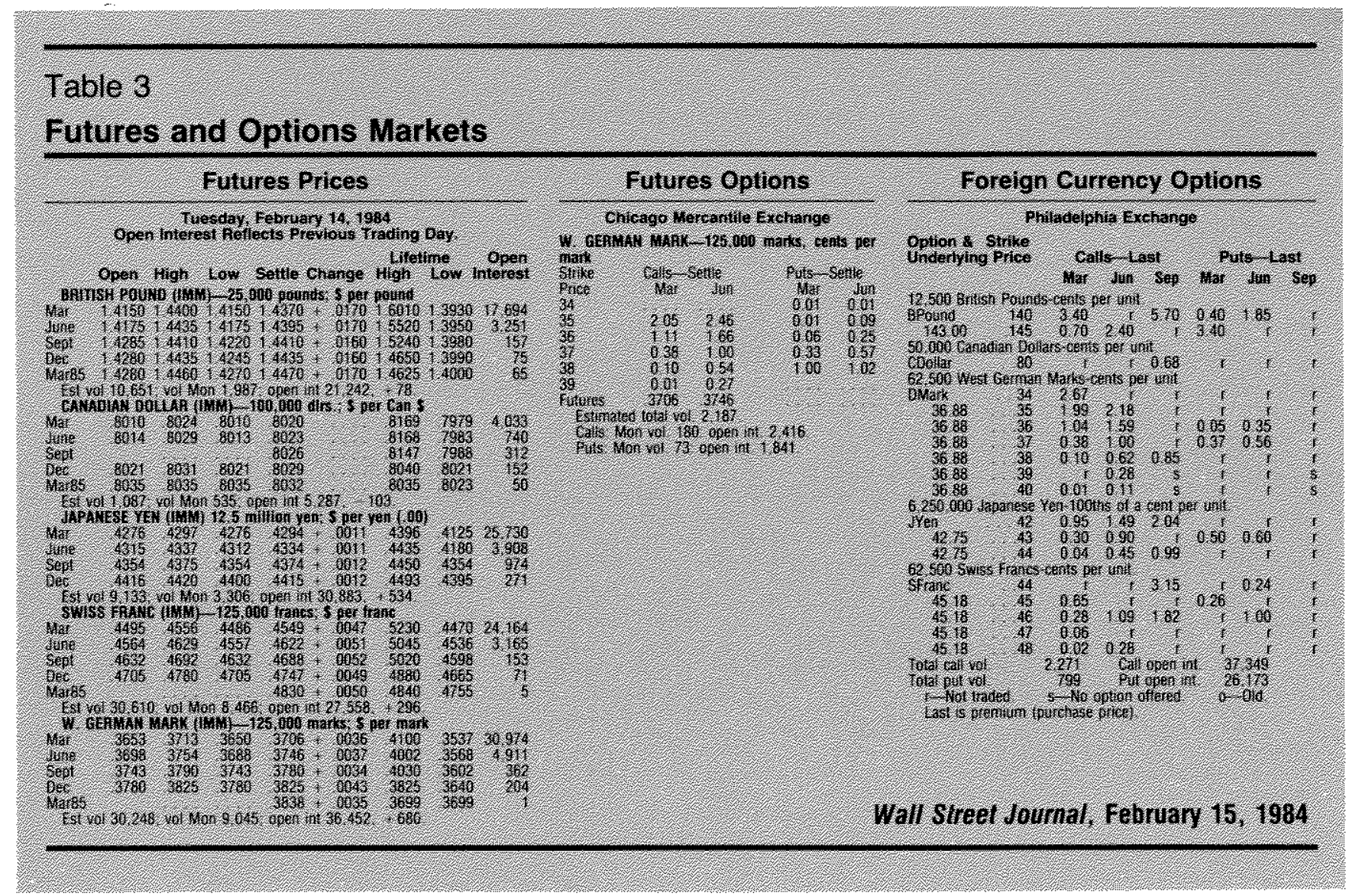

The March call option at strike price $\$ .3900$ per mark costs ony 0.01 cents per mark or $\$ 12.50$. These price differences indicate that the market expects the dollar price of the mark to exceed $\$ .3500$, but not to rise substantially above $\$ .3900$.

Notice that when you exercise a futures call option you buy the relevant futures contract but only fulfill that futures contract at maturity. In contrast, the Phitadelphia foreign currency options (right column) are options to buy foreign exchange (spot) itself rather than futures. So, when a call option is exercised, foreign currency is obtained immediately.

The only difference in presentation of the currency opion prices as compared with the futures options is that, in the former, the spot exchange rate is listed for comparison rather than the futures price. Thus, on the Philadelphia exchange, call options on March DM 62,500 at strike price $\$ .3500$ per mark cost 1.99 cents per makk or $\$ 1,243.75$, plus brokerage. Brokerage fres here would be of the same order as on the IMM, about $\$ 16$ per transaction round trip, per contract.

We have seen that there are several different markets for foreign exchange - spot, forward, futures, options on spot, options on futures. The channels through which these markets are formed are, however, fairly straightforward (see figure 1). The main channel is the interbank network, though for large interbank transacm tions, foreign exchange brokers may be used as middlemen.

\section{FOREIGN EXCHANGE MARKET ACTIVITITS}

Much foreign exchange market trading does not appear to be related to the simple basic purpose of allowing businesses to buy or sell foreign curtency in order, say, to sell or purchase goods overseas. It is certainly easy to see the usefulness of the large range of foreign exchange transactions available through the interbank and organized markets ispol, forward, futures, options) to facilitate trade between nations. It is also clear that there is a usefut role for foreign exchange brokers in helping to "make" the interbank market. "There are several othor activities, however, in foreign exchange markets that are less well understood and whose relevance is less obvious to people interested in understanding what these markets accomplish. 


\section{Foreign Exchange Options}

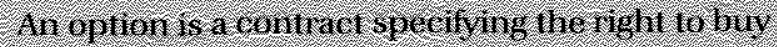

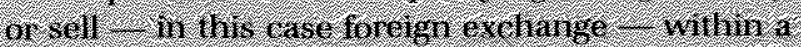

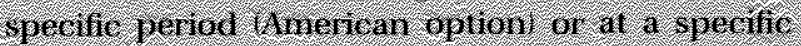

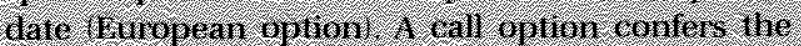

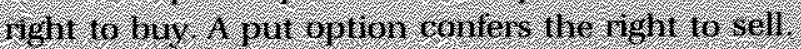

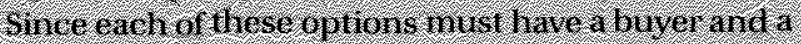

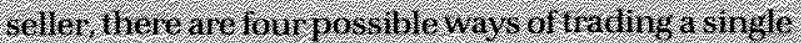

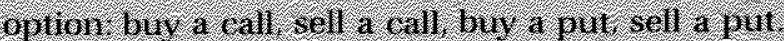

The biver of al option has whe nght to dimclentake

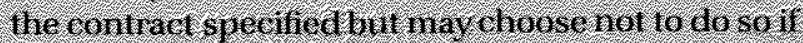
it hins out ho be unoromale. the seller of he

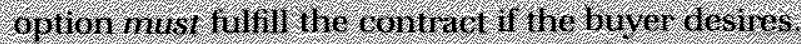

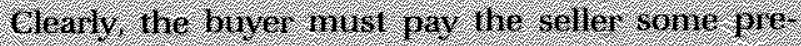

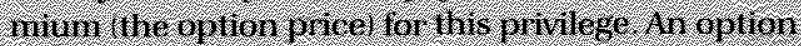

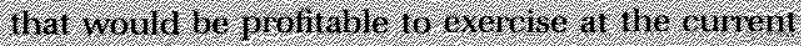

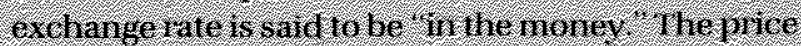

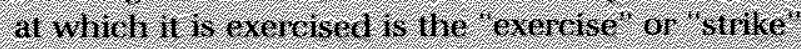
pirice

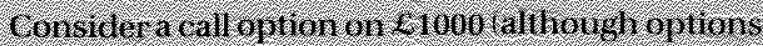

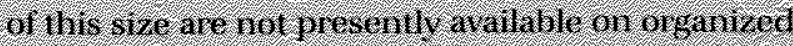

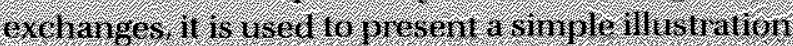

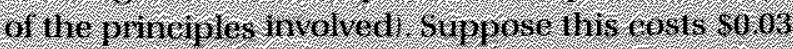

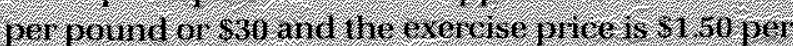

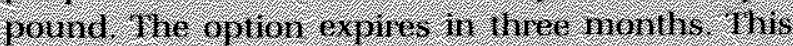

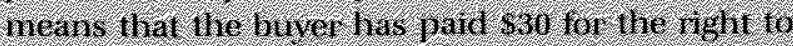

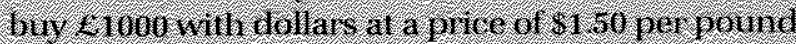

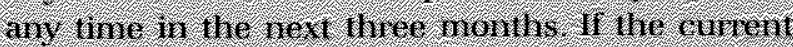

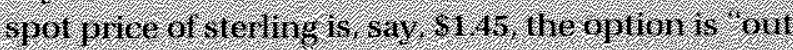

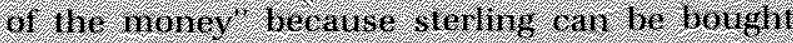

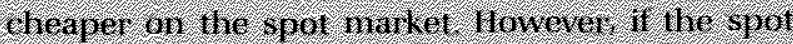

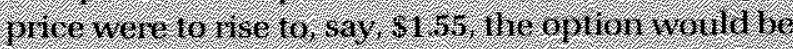

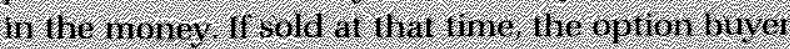

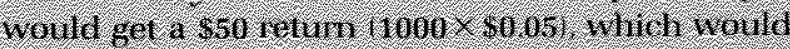

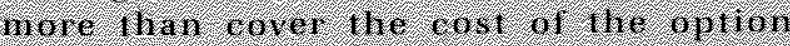

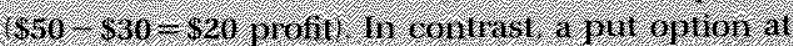

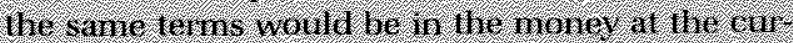

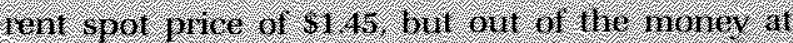
1.156.

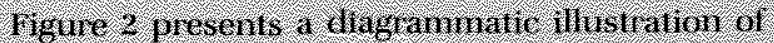

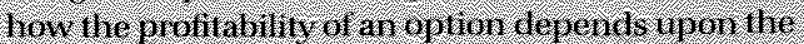

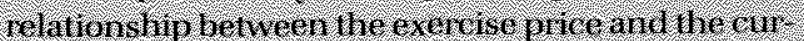

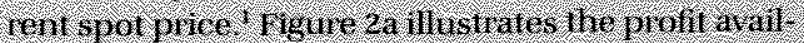

\footnotetext{
The prieing of options has been the subiect of a large heoretical Iiterature Will a najer coniribulion being nade 6 y Back and Scholds $(1973)$. The Elack-Schous (ornula has been nodined. (or toreign oxchange optrons by Gaman and hothagen (1983)

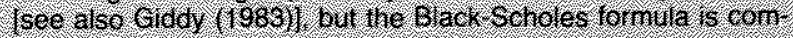
plex and bejond hie scope of the present paper
}

T. 0.18 .2

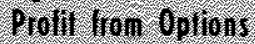

(a)

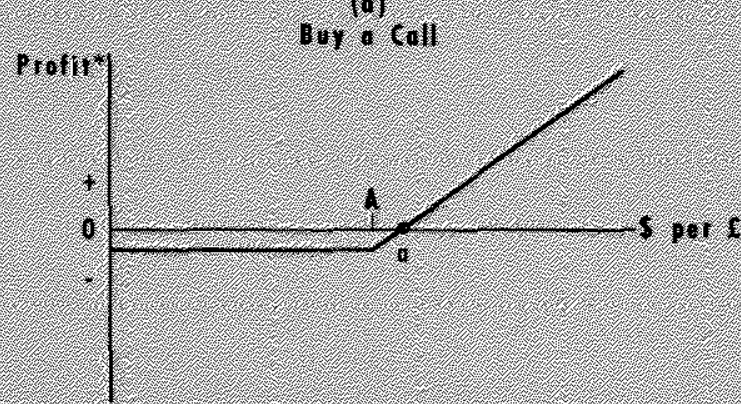

(1)

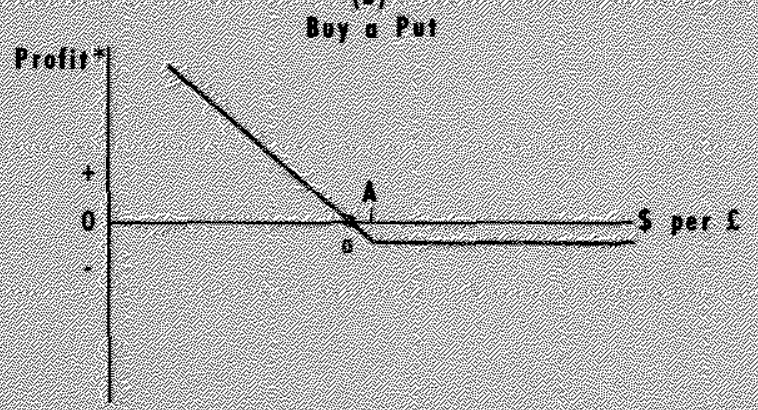

(4)

Bur o stroddle

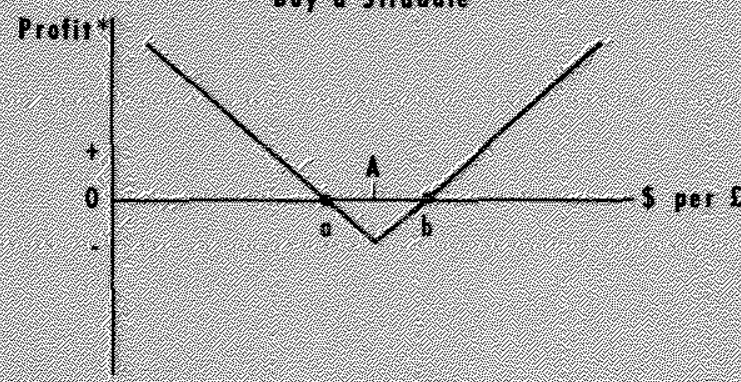

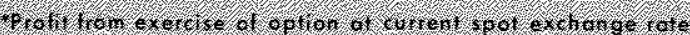

One simple rotatonship which is of hiterest hav be cailec option orice party: Whis anses because atbilrage wil ehsure

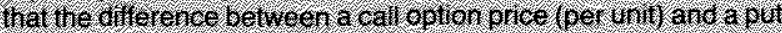

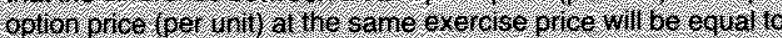
The present value of the difference between the exereise price and the 10 ward exehange rate at naturity of the oplens of the options are na ketable. W will also held for any date 10 naturly) The relationship nay be expressed

C.

Wen C and P are tho cal and pul option pices at exercise price E. F is the forward 6 chanco rate and is the ifiterest rate per berod of the centracts. This arses because the simultaneous buing of a call and seling or a pur is equivalent to tuyine allency torward at phes $\mathrm{E}$. The tomard contract however

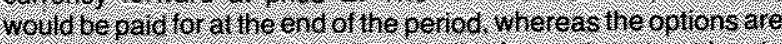
transacted at the beainning. Hetee the to ward comtract has to be discounted baek to the presen. 
able fiom bowing a call option at exerase prite $A$. At spot exchange tate 1 ind anvthrig lower the option Will not bre exereised so the loss will equal the price of the option at a spot exchange inte dhove a the Gytion is stificienlly th the nowey 10 more than cover it cost Between $A$ and a the option is in the money bat ant by enought to cover eost the proffi from selling a call could he fllustrated ly veversing the 1 and - signs in figure 2a, or by lipping the profit line thout the horizontal axis.

Rigure 26 ilhistrates the profit from buving a put option. At spot exchange rates below a, the option with exercise price A will shon a profit

Tigure 2r illustrates the profit from a simul. tanemus purchase of a phit and tall at the same exerese price. This combination wil show a piofi at exercise pree. A it the spot pite goes either ahove h or below a. It is known as it straddle the strad. ale is of specal interest hecatse it makes clear the role of options as a hedge against nisk. The unee of a stratdte can le regarder as he malket ualuation ol the variahiliv of the ex elangerate. That is the byy er of the stradele will show a proit if the spot price moves tron some central value the exarcise pilce by rmore than plus ur nimits some known percent age. The seller or the stradille accepts hal risk for a limp sum More complicated inulipile stratestes: are also possible?

2see (1) (d) ( 983$)$
Two major classes of activity will be discussed. First, the existence of a large number of foreign exchange markets in many locations creates opportunities to profit from "arbitrage." Second, there is implicitly a market in (foreign exchange) risk bearing. Those who wish to avoid foreign exchange risk (at a price) may do so. Those who accept the risk in expectation of profits are known as "speculators."

\section{Triangular Arbitrage}

Triangular arbitrage is the process that ensures that all exchange rates are mutually consistent. If, for example, one U.S. dollar exchanges for one Canadian dollar, and one Canadian dollar exchanges for one British pound, then the U.S. dollar-pound exchange rate should be one pound for one dollar. If it differs, then there is an opportunity for profit making. To see why this is so, suppose that you could purchase two U.S. dollars with one British pound. By first buying $C \$ 1$ with U.S. $\$ 1$, then purchasing $E 1$ with $C \$ 1$, and finally buying U.S.\$2 with $£ 1$, you could double your money immediately. Clearly this opportunity will not last for long since it involves making large profits with certainty. The process of triangular arbitrage is exactly that of finding and exploiting profitable opportunities in such exchange rate inconsistencies. As a result of triangular arbitrage, such inconsistencies will be eliminated rapidly, Cross rates, however, will only be roughly consistent given the bid-ask spread associated with transaction costs.

In the past the possibility of making profits from triangular arbitrage was greater as a result of the prac- tice of expressing exchange rates in American terms in the United States and in European terms elsewhere. The adoption of standard practice has reduced the likelihood of inconsistencies. ${ }^{7}$ Also, in recent years, such opportunities for profit making have been greatly reduced by high-speed, computerized information systems and the increased sophistication of the banks operating in the market.

Arbitrage of a slightly different kind results from price differences in different locations. This is "space" arbitrage. For example, if sterling were cheaper in London than in New York, it would be profitable to buy in London and sell in New York. Similarly, if prices in the interbank market differed from those at the IMM, it would be profitable to arbitrage between them. As a result of this activity, prices in different locations will be brought broadly into line.

\section{Interest Arbitrage}

Interest arbitrage is slightly different in nature from triangular or space arbitrage; however, the basic motive of finding and exploiting profitable opportunities still applies. There is no reason why interest rates denominated in different currencies should be equal. Interest rates are the cost of borrowing or the return to lending for a specific period of time. The relative price lexchange ratel of money may change over time so that the comparison of, say, a U.S. and a British interest rate requires some allowance for expected exchange rate changes. Thus, it will be not at all unusual to find

${ }^{7}$ All except U.K. and lrish exchange rates are expressed in American terms. Futures and options contracts are expressed in European terms. 
interest rates denominated in dollars and interest rates denominated in, say, pounds being somewhat different. However, real returns on assets of similat quality should be the same if the exchange rate risk is covered or hedged in the forward market. Were this not true, it would be possible to borrow in one currency and lend in another at a profit with no exchange risk.

Suppose we lend one dollar for a year in the United States at an interest rate of $F_{i x}$. The amount accumulated at the end of the year per dollar lent will be $1+r_{u s}$ (capital plus interest). If instead of making dollar loans, we converted them into pounds and lent them in the United Kingdom at the rate ruk, the amount of pounds we would have for each original dollar at the end of the year would be $S\left(1+r_{t a k}\right)$, where $S$ is the spot exchange rate (in pounds per dollar) at the beginning of the period. At the outset, it is not known if $1+r_{u s}$ dollars is going to be worth more than $S\left(1+r_{u k}\right)$ pounds in a year's time because the spot exchange rate in a year's time is unknown. This uncertainty can be avoided by selling the pounds forward into dollars. Then the relative value of the two loans would no longer depend on what subsequently happens to the spot exchange rate. By doing this, we end up with $\frac{\mathfrak{s}}{\mathrm{F}^{*}}\left(1+\mathrm{r}_{\mathrm{k}}\right)$ dollars per original dollar invested. This is known as the "covered," or hedged, retum on pounds.

Since the covered retum in our example is denominated in dollars, it can reasonably be compared with the U.S. interest rate. If these returns are very different, investors will move funds where the return is highest on a covered basis. This process is interest arbitrage. It is assumed that the assets involved are equally safe and, because the returns are covered, all exchange risk is avoided. Of course, if funds do move in large volume between assets or between financial centers, then interest rates and the exchange rates (spot and forward) will change in predictable ways. Funds will continue to flow between countries until there is no extra profit to be made from interest arbitrage. This will occur when the retums on both dollar-and sterling-denominated assets are equal, that is, when

(1) $\left(1+\mathrm{F}_{\mathrm{USS}}\right)=\frac{\mathrm{s}}{\mathrm{F}}\left(1+\Gamma_{\mathrm{Luk}}\right)$.

This result is known as covered interest parity. It holds more or less exactly, subject only to a maggin due to transaction costs, so long as the appropriate dollar and sterling interest rates are compared. ${ }^{8}$

\footnotetext{
${ }^{8}$ Since there are many different interest rates, it obviously cannot hold for all of them. Where (1) does hold is if the interest rates chosen are eurocurrency deposit rates of the same duration. In other words, if for
}

\section{Spectalation}

Arbitrage in the foreign exchange markets involves little or no risk since transactions can be completed rapidly. An atternative source of profit is available from outguessing other market participants as to what future exchange rates will be. This is called speculation. Although any foreign exchange transaction that is not entirely hedged forward has a speculative element, only deliberate speculation for profit is discussed here.

Until recently, the main foreign exchange speculators were the foreign exchange departments of banks, with a lesser role being played by portfolio managers of other financial institutions and intemational corporations. The IMM, however, has made it much easier for individuals and smaller businesses to speculate. A high proportion of IMM transactions appears to be speculative in the sense that only about 5 percent of contracts lead to ultimate delivery of foreign exchange. This means that most of the activity involves the buying and selling of a contract at different times and possibly different prices prior to maturity. It is possible, however, that buying and selling of contracts before maturity would arise out of a strategy to reduce risk. So it is not possible to say that all such activity is speculative.

Speculation is important for the efficient working of foreign exchange markets. It is a form of arbitrage that occurs across time rather than across space or between markets at the same time. Just as arbitrage increases the efficiency of markets by keeping prices consistent, so speculation increases the efficiency of forward, futures and options markets by keeping those markets liquid. Those who wish to avoid foreign exchange risk may thereby do so in a well-developed market. Without speculators, risk avoidance in foreign exchange markets would be more difficult and, in many cases, impossible.

\section{Firsh Peduchion}

Speculation clearly involves a shifting of risk from one party to another. For example, if a bank buys for-

\footnotetext{
$r_{u s}$ we take, say, the three-month eurodollar deposit rate in Paris and for $r_{i k}$ we take the three-month eurosterling deposit rate in $P$ aris, then (1) will hold iust about exactly. Indeed, if we took the interest rate and exchange rate quotes all from the same bank, it would be remarkable if (1) did not hold. Otherwise the bank would be offering to pay you to borrow from it and lend straight back! That is, the price of borrowing would be less than the covered return on lending. A margin between borrowing and lending rates, of course, will make this even less likely so that in reality you would lose.

${ }^{9}$ This is not to say that all speculative activity is necessarily beneficial.
} 


\section{Covered Interest Parity: An Example}

The following inferest rate and exchange rate quotations are taken from the lendon funancial Times or septenber 8, 1983 table 1 .

\section{Closing}

Txchange Nate dollars per

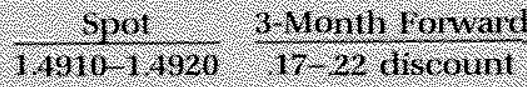
poline

Intcrest narest 6. Non (10)

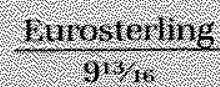

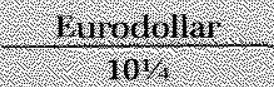

Finte

The interest rate on the ther - Monhl guradillat

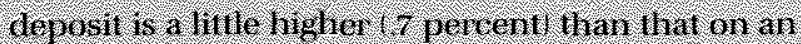

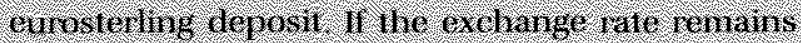
unchugged, it would ho hetter ro hold dollars, if the

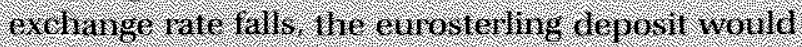

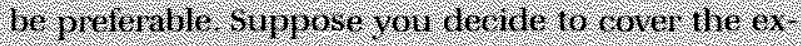
change its lo seling the allits for ward into

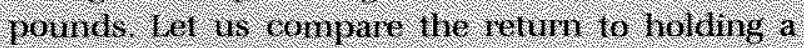

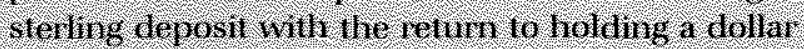
deposit sold forvare niro stering hssimms that poir start with stering

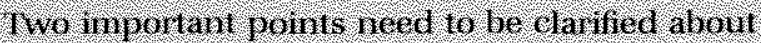

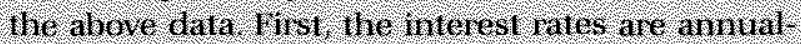
1hed so hret are not what would ar hially be canged

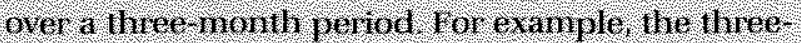

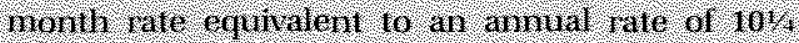
peratil is 2.47 percent

secrond, the rom whd exchange rates herd some explaniation, 1 he dollar is at a discount aganst ster.

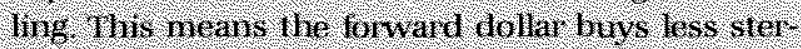
ling se we have th add the discolnt onto the spol

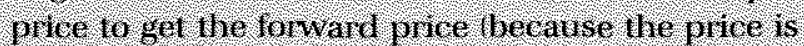
The number of dollars per pownd, hot he reversel.

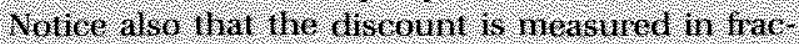
tions of a cent not hactions of a dollart so whe

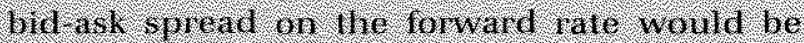
$144927-14942$

Now let us set it he wovid do better to muest in a

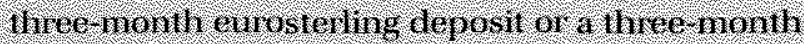

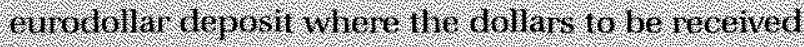

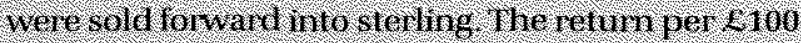

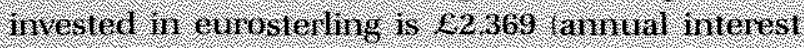

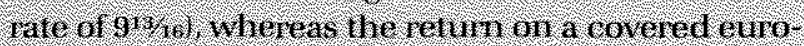
allitu coposit is

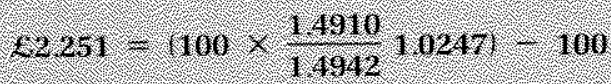

This. we gulld not nake a proft gut of bovered

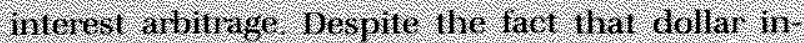

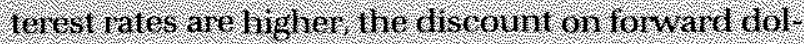
lars in the for want nark of means 1 goy buy rewer

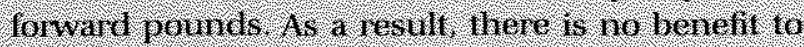

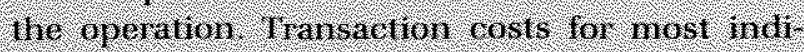
vilutis would be even grater than 1 hose above as they wolld rage a larger bid ask spread wan what

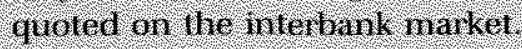

consequenty. Where is no benent for he typieal hovestor tron making a covered or l

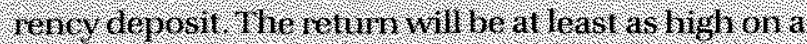
deposit in the climenoy in wheh you start and wish to end up. That is, if you have dollars and wish to end yy with dollars, nake a emodollar deposil. If

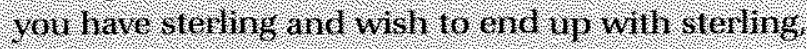
hake a equostering deposil Ir vou have sterling and wish to ond wi in dollats, here is likely to be litile or no difference between holang a elmosluting de posit sold fon ward into collars on buymg dollars spor and holding a curodlollar deposit or course, it vou hold an ' unrovered' deposit and exehange rates substguemuly change, lhe result will be wery diflerent ward foreign exchange from a customer $r_{f}$ it increases its exposute to risk while the customer reduces his. However, there is not a fixed amount of risk that has to be "shared out. ${ }^{+7}$ Some strategies may involve a net reduc" tion of risk all around.

As a general rule, financial institutions (or other firms , operating in a variety of currencies, will try to minimize the risk of losses due to unexpected exchange rate changes. One simple way to do this is to ensure that assets and liabilities denominated in each operating currency are equal. This is known as "matching." for example, a bank that sells sterling forward to a customer may simultaneously buy sterling forward. In this event, the bank is exposed to zero exchange rate risk. 


\section{Why Is the Dollar the "Money" of Foreign Exchange Markets?}

One interesting aspect of the organization of the foreign oxohange narkets is that the "money used in mese narkets is generally the Us. dontr This is generally true for spor markets and universally inue for forward narkets. Cross mankets batween many cumencies are ven ihin and future cross markets are virtually nonexistent ror example the buik of foreign exchange trading herween $f$ s and

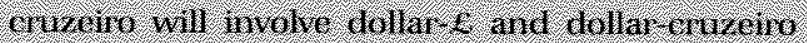
transactions instead of direct 4 entizeirs trading. The only exception to his is the thansactions mulv. ing ite nator Organization for Eecononite Coopera tion and revtopment (OL CD) curfencies, espectal. V. within turope of the $\$ 702,5$ hillion tumover in forengn exchange teported by US. banks in Apmi 1983, anly st 5 billion dic not inolve US dollars.

There ant two explanations for his spectial role of the dollar in foreign exchange makets. Boih nely tipoin the fact that transaction eosts are likely to he lower if the dollar is used as a metimm Irugman shows that the clearing of foreign exchange mankets requires some: intermediary chriency? Ren if ev:

sece rugman (1980) ery counthy is in payments balance vis it wis the rest of the World, it wil nut recessarily be in bilateral balance will cach ottier comminy Because sone cur reney has to be used to cover this residnal finance it is natural to choose the currency that has the lowest iransaction cests Chivstal shows lliere are eco: nomic reasons wh cross-markets between many. aurencies do not exisi I I Iypically will be easior and theaper to set up a deat in two steps via the dollar than in a smgle step criveino-dollar. dollar: diachna father than crizeiro drachmat. This is be: rause liese cross markets, If Hey existed, would be faity thin and hence telatively cosily for such thans. actions. The twe makets with the dellar on the other trand, are well developed.

These malyses refer to the fole of the dollar in the interhank market. In the developmen of the tradnes places sueh as 17 re $\mathrm{MM}$ in Clireago and Jimt in fondom to date. it is atso the that all eurtency thtures are traded toamst he dollar.

See onviral ( 1982$)$
Banks often use "swaps" to close gaps in the maturity structure of their assets and liabilities in a currency. This involves the simultaneous purchase and sale of a currency for different maturity dates. In April 1983, 33 percent of U.S. banks' foreign exchange turn over involved swaps as compared with 63 percent spot contracts and only 4 percent outright forward contracts. ${ }^{10}$

Suppose a bank has sold DM to a customer three months forward and bought the same amount of DM from a different customer six months forward. There are two ways in which the bank could achieve zero foreign exchange risk exposure. It could either under* take two separate offsetting forward transactions, or it could set up a single swap with another bank that has the opposite mismatch of dollar-DM flows whereby it receives DM in exchange for dollars in three months and receives back dollars in exchange for DM in six

\footnotetext{
${ }^{10}$ See Federal Reserve Bank of New York (1983).
}

months. Once the swap is set up, the bank's net profits are protected against subsequent changes in spot exchange rates during the next six months.

Within the limits imposed by the nature of the contracts, a similar effect can be achieved by an appropriate portfolio of futures contracts on the IMM. Thus, a bank would buy and sell futures contracts so as to match closely its forward commitments to customers. In reality, banks will use a combination of methods to reduce foreign exchange risk.

Markets that permit banks, firms and individuals to hedge foreign exchange risk are essential in times of fluctuating exchange rates. This is especially important for banks if they are to be able to provide efficient foreign exchange services for their customers. In the absence of markets that permit foreign exchange risk hedging, the cost and uncertainty of international transactions would be greatly increased, and international specialization and trade would be greatly reduced. 


\section{CONGLUSION}

The foreign exchange markets are complex and, for the outsider, hard to comprehend. The primary function of these markets is straightforward. It is to facilitate international transactions related to trade, travel or investment. Foreign exchange markets can now accommodate a large range of current and forward transactions.

Given the variability of exchange rates, it is important for banks and firms operating in foreign currencies to be able to reduce exchange rate risk whenever possible. Some risk reduction is achieved by interbank swaps, but some is also taken up by speculation. Arbitrage and speculation both increase the efficiency of spot and forward foreign exchange markets and have enabled foreign exchange markets to achieve a high level of efficiency. Without the successful operation of these markets, the obstacles to international trade and investment would be substantial and the world would be a poorer place.

\section{MloGSaIy.
A merican option - an option that can be exercised any line} us to maturity

American ternis - an oxchange rate expressed as number of currency unis per doltat:

arbiltrage - the simulaneous purchase and sale of currency in separate narkets tor a profit arising trom a price discrepancy between he makets:

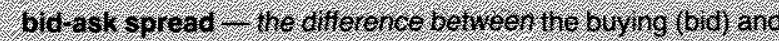
seling (ast) orreo

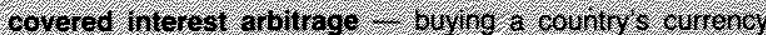
spor nvesting tor a period, and selling tie ploceeds torwald h

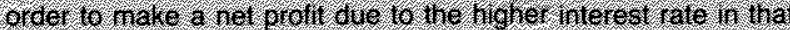

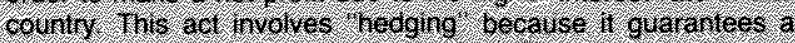

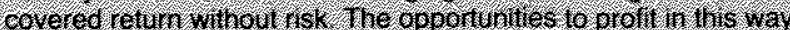
sel6om arise because covered interesl cilleretitats are norrualy $6105 e 102010$

covered thterest paity - the gao between hierest rates in

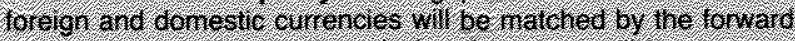
exchange ale dilerenthal sich 1 hat the covered hierest hate dierental willie chese to zero.

eurodollar deposits - bank oeposis. generaly beanth in

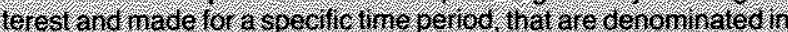
dollars butare in banks ourside the L riled states. Sinilaty, euro. stetha deposits would be denominated in steling but outside the Uined Kingdam

European option - anoption thet can be exercised orily ona Stectiver date

European terms - an exchange rale expressed as number of collars per curtency unil

floathg excharige rate . an exchange tate that is alloved to

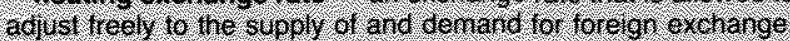

toreigh orchange speculation - the act Gl taking a net post.

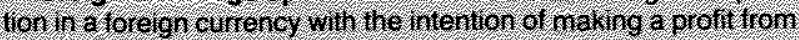
exchange rate oharges.

forward exchange rate the phice of toreign currehcy tor dentery a a tulure date agreed to by a contrach toray

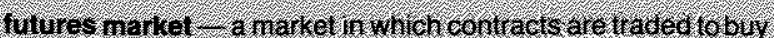
or sell a standard anourt ot curency in the future at a paricular price

hedging or covering exchange rst. means wha foreign cur rehery is sold forward into local curency so that its value is noi atrected by subsequent exchange rate chahges say an experter

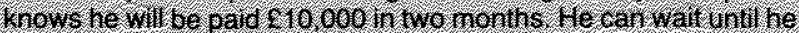

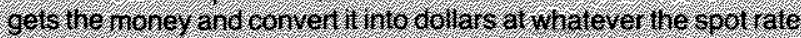

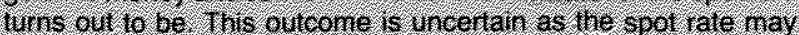

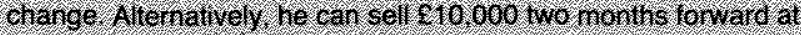

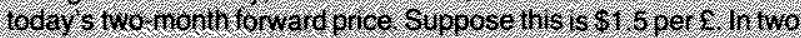

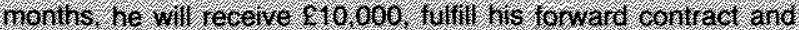
receve 8 if 000 . This export con trach has been hedged ar covered in the coiware nareet

natching - equathg assets and robilies denominated in

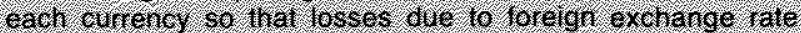
changes are ninimized.

options market. a narkel in Which contracts are traded that

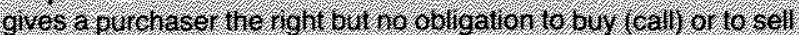

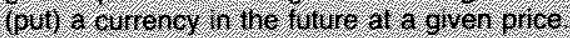

spot exchange rate. - the phoe pad to exchange eirenctes for minedrate deluber (two business days in the nterbant narket or over ho counter in the etall and tavelers check market)

swap - the sinulitareous purchase and sale of a curtency for diferent matunty dates that closes the gaps in the maturity struc. trre of assets and habilies in 2 cumench 


\section{REFERENCES}

Belongia, Michael T. "Commodity Options: A New Risk Management Tool for Agricultural Markets," this Review (June/July 1983) pp. 5-15.

Black, Fisher, and Myron Scholes. "The Pricing of Options and Corporate Liabilities," Joumal of Political Economy (May/June 1973). pp. 637-54.

Chrystal, K. Alec. "On the Theory of International Money" (paper presented to U.K. International Economics Study Group Conference, September 1982, Sussex, England). Forthcoming in J. Black and G. S. Dorrance, eds., Problems of international Finance (London: Macmillan, 1984).

Dufey, Gunter, and tan H. Giddy. The International Money Market (Prentice-Hall, 1978).
Federat Reserve Bank of New York. "Summary of Results of U.S. Foreign Exchange Market Turnover Survey Conducted in April $1983^{\prime \prime}$ (September 8, 1983).

Garman, Mark B., and Steven W. Kohthagen. "Foreign Currency Option Values," Journal of International Money and Finance (Decernber 1983), pp. 231-37.

Giddy, Ian $\mathrm{H}$. "Foreign Exchange Options," Journal of Futures Markets (Summer 1983), pp. 143-66.

Krugman, Paul. "Vehicle Currencies and the Structure of International Exchange," Journal of Money, Credit and Banking (August 1980), pp. $513-26$.

Kubarych, Roger M. Foreign Exchange Markets in the United States. (Federal Reserve Bank of New York, 1983).

Mckinnon, Ronald I. Money in International Exchange: The Converfible Currency System (Oxford University Press, 1979). 